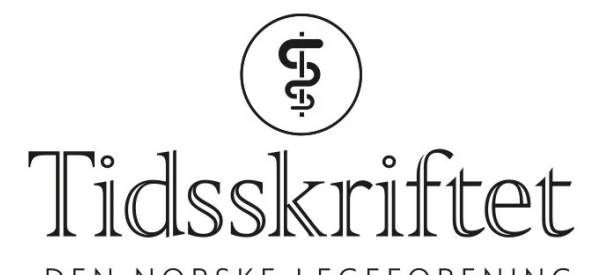

DEN NORSKE LEGEFORENING

\title{
Utprøvende behandling ved covid-19
}

\section{LEDER}

\section{ARNE BROCH BRANTSATER}

uxarbr@ous-hf.no

Arne Broch Brantsæter er overlege ved Infeksjonsmedisinsk avdeling, Oslo universitetssykehus og Nasjonal behandlingstjeneste for CBRNE-medisin. Han har vært konsulent for WHO under sarsepidemien i 2003 og under den pågående pandemien.

Forfatteren har fylt ut ICMJE-skjemaet og oppgir ingen interessekonflikter.

\section{Hva gjør vi uten legemidler med sikker effekt?}

I 2003 stod verden på randen av en pandemi med alvorlig luftveisinfeksjon forårsaket av det nye koronaviruset SARS-CoV. Viruset rakk å spre seg fra Kina til 28 land før det - etter bare få måneder - var bekjempet under ledelse av Verdens helseorganisasjon (WHO). Ni år senere ble et nytt dødelig koronavirus, i dag kjent som MERS-CoV, oppdaget i Midtøsten. Der gir det fortsatt utbrudd av luftveisinfeksjonen mers, med sporadisk eksport av tilfeller utenfor regionen. En rekke medikamenter har blitt forsøkt i behandlingen av både sars og mers, uten at dette har resultert i legemidler med tilstrekkelig dokumentert effekt.

I januar 2020 rettet verden på nytt oppmerksomheten mot Kina og millionbyen Wuhan. Et nytt sarsvirus, SARS-CoV-2, forårsaket utbrudd med den alvorlige luftveisinfeksjonen vi i dag kjenner som covid-19. Senere kom det en strøm av rapporter om utprøvende medikamentell behandling, bl.a. med tradisjonell kinesisk medisin, glukokortikoider, plasma, hiv- og malariamedisin (1). Gjennom svært inngripende tiltak fikk Kina kontroll på sykdommen. Dette hindret allikevel ikke at viruset spredte seg utenfor Kinas grenser, hvor det har ført til den verste pandemien siden spanskesyken for over 100 år siden. Vestlige land fulgte Kina med utprøvende behandling i stort omfang og med vekt på rask publisering av resultatene. Ofte har dette vært forskning av ujevn kvalitet som er publisert uten fagfellevurdering gjennom såkalte preprints.

Utprøvende behandling er definert som all behandling der effekt, risiko og bivirkninger ikke er tilstrekkelig dokumentert til at behandlingen kan inngå i det ordinære behandlingstilbudet. Når vi mangler medikamenter med tilstrekkelig dokumentasjon, har vi tre valg: inkludere pasienten i kliniske studier, gi «noe» basert på usikkert grunnlag og håp om effekt eller å avstå fra behandling i påvente av resultater fra vitenskapelige studier.

Inklusjon i en klinisk studie er klart å foretrekke, da dette kan bidra til å dokumentere et legemiddels effekt og sikkerhet. Helsedirektoratet og Legemiddelverket ønsker derfor at utprøvende behandling som hovedregel skal foregå gjennom kliniske studier $(\underline{2}, 3)$. Men når inklusjon i en studie ikke er et alternativ, kan det ved alvorlig sykdom være vanskelig å avstå fra mer eller mindre godt funderte og alltid velmente terapiforsøk. Utprøvende 
behandling utenfor studier har vi sett mange eksempler på under pandemien, men ulempen er at dette i verste fall kan forverre sykdommen - uten at erfaringene bidrar til å dokumentere hverken effekt eller sikkerhet. Disse problemstillingene har vært hyppig diskutert i relasjon til covid-19 gjennom de siste månedene. To artikler som nå publiseres $\mathrm{i}$ Tidsskriftet, gir innsikt i dette $(\underline{4}, 5)$.

\section{«Inklusjon i en klinisk studie er klart å foretrekke, da dette kan bidra til å dokumentere et legemiddels effekt og sikkerhet»}

Eirik Hugaas Ofstad og medarbeidere ga en pasient både malariamedisinen hydroksyklorokin og det immunmodulerende medikamentet metylprednisolon. De observerte klinisk bedring to dager etter oppstart av steroidbehandling (4). I ettertid er effekt av hydroksyklorokin ved covid-19 avkreftet i flere studier (므). Deksametason, som i likhet med metylprednisolon er et glukokortikoid, ser derimot lovende ut, og den britiske Recovery-studien har vist redusert dødelighet etter deksametasonbehandling for covid-19pasienter som ble behandlet på respirator eller trengte oksygentilførsel (7.). Michael Hahn og kollegaer presenterer erfaringer med bruk av rekonvalesensplasma til en pasient, og ser sammenfall i tid mellom administrering av plasma og bedring av sykdommen (5). Forfatterne konkluderer allikevel med at man på dette grunnlaget ikke kan si noe om behandlingens effekt.

Norge er et lite land i covid-19-sammenheng, og det er derfor ønskelig at vi deltar i store, internasjonale, randomiserte, kontrollerte studier. På den måten bidrar vi best til dokumentasjon av legemidlers effekt og sikkerhet. Norge var blant de første landene som kom med i WHOs Solidarity-studie, og det er svært gledelig at 29 norske sykehus er med i denne (므). Internasjonalt har studien allerede bidratt til å avdekke manglende effekt av hydroksyklorokin og hivmedikamentet lopinavir/ritonavir ( $\underline{6})$. Foreløpige resultater fra den amerikanskledede ACTT-1-studien tyder på at remdesivir, opprinnelig et mislykket ebolamedikament, reduserer tid til bedring med noen dager, men uten sikker effekt på dødelighet ( $\underline{8}$ ). De europeiske legemiddelmyndighetene (EMA) har på dette grunnlaget gitt remdesivir en betinget godkjenning for behandling ved covid-19. I Norge har man foreløpig oppfordret til å være tilbakeholden med bruk av remdesivir, utenom Solidarity-studien, inntil resultater om legemiddelets effekt fra denne studien er klare.

Det er vaksine og ikke legemidler som kan stanse denne pandemien. Men i påvente av effektiv vaksine vil effektive legemidler i beste fall kunne forebygge og lindre sykdom, redde liv og avlaste en presset helsetjeneste. Varsellampene har blinket både under sars og mers uten at dette har ført til tilstrekkelig prioritering av forskning på legemidler mot koronavirus. Nå haster det!

\section{LITTERATUR}

1. World Health Organization. Report of the WHO-China Joint Mission on Coronavirus Disease 2019 (COVID-19). https://www.who.int/docs/default-source/coronaviruse/who-china-joint-mission-oncovid-19-final-report.pdf Lest 18.8.2020.

2. Helsedirektoratet. Utprøvende behandling - nasjonale prinsipper. Nasjonal veileder, 2019. https://www.helsedirektoratet.no/veiledere/utprovende-behandling Lest 18.8.2020.

3. Statens legemiddelverk. Utvikling og utprøving av legemidler til behandling av covid-19. https://legemiddelverket.no/godkjenning/legemidler-og-vaksiner-mot-covid-19/utvikling-ogutproving-av-legemidler-til-behandling-av-covid-19 Lest 18.8.2020.

4. Ofstad EH, Hauglid T, Tollåli T et al. Pasient med alvorlig covid-19 behandlet med steroider. Tidsskr Nor Legeforen 2020; 140. doi: 10.4045/tidsskr.20.0524. [CrossRef]

5. Hahn M, Huanca-Condori ME, Totland A. Pasient med alvorlig covid-19 behandlet med rekonvalesensplasma. Tidsskr Nor Legeforen 2020; 140. doi: 10.4045/tidsskr.20.0501. [CrossRef] 
6. World Health Organization. "Solidarity" clinical trial for COVID-19 treatments: Latest update on treatment arms. https://www.who.int/emergencies/diseases/novel-coronavirus-2019/global-researchon-novel-coronavirus-2019-ncov/solidarity-clinical-trial-for-covid-19-treatments Lest 16.8.2020.

7. Horby P, Lim WS, Emberson JR et al. Dexamethasone in hospitalized patients with Covid-19Preliminary report. N Engl J Med 2020; 382: NEJMoa2021436. [PubMed][CrossRef]

8. Beigel JH, Tomashek KM, Dodd LE et al. Remdesivir for the treatment of Covid-19- Preliminary report. N Engl J Med 2020;382: NEJMoa2007764. [PubMed][CrossRef]

Publisert: 24. august 2020. Tidsskr Nor Legeforen. DOI: 10.4045/tidsskr.20.0653

(C) Tidsskrift for Den norske legeforening 2023. Lastet ned fra tidsskriftet.no 26. april 2023. 